\title{
Pheochromocytoma and Paraganglioma cM1a TNM Finding v8
}

National Cancer Institute

\section{Source}

National Cancer Institute. Pheochromocytoma and Paraganglioma CM1a TNM Finding

v8. NCI Thesaurus. Code C141110.

Distant metastasis to only bone. (from AJCC 8th Ed.) 